\title{
Review \\ Stem Cell and Macrophage Roles in Skeletal Muscle Regenerative Medicine
}

\author{
Pasqualina Scala ${ }^{1}$, Laura Rehak ${ }^{2}$, Valentina Giudice ${ }^{1,3,4}{ }^{\mathbb{D}}$, Elena Ciaglia ${ }^{1}$, Annibale Alessandro Puca ${ }^{1,5} \mathbb{D}$, \\ Carmine Selleri ${ }^{1,3}\left(\mathbb{D}\right.$, Giovanna Della Porta ${ }^{1,6, *(D)}$ and Nicola Maffulli ${ }^{1,7}$
}

1 Department of Medicine, Surgery and Dentistry, University of Salerno, Via S. Allende, 84081 Baronissi, Italy; pscala@unisa.it (P.S.); vgiudice@unisa.it (V.G.); eciaglia@unisa.it (E.C.); apuca@unisa.it (A.A.P.); cselleri@unisa.it (C.S.); nmaffulli@unisa.it (N.M.)

2 Athena Biomedical Innovations, Viale Europa 139, 50126 Florence, Italy; laurarehak@gmail.com

3 Hematology and Transplant Center, University Hospital "San Giovanni di Dio e Ruggi D’Aragona", Largo Città d'Ippocrate 1, 84131 Salerno, Italy

4 Clinical Pharmacology, University Hospital "San Giovanni di Dio e Ruggi D’Aragona”, Largo Città d'Ippocrate 1, 84131 Salerno, Italy

5 Cardiovascular Research Unit, IRCCS MultiMedica, Via Milanese 300, 20138 Milan, Italy

6 Interdepartment Centre BIONAM, University of Salerno, Via Giovanni Paolo I, 84084 Fisciano, Italy

7 Centre for Sports and Exercise Medicine, Barts and The London School of Medicine and Dentistry, Queen Mary University of London, 275 Bancroft Road, London E1 4DG, UK

* Correspondence: gdellaporta@unisa.it; Tel./Fax: +39-089-965-234

Citation: Scala, P.; Rehak, L.;

Giudice, V.; Ciaglia, E.; Puca, A.A.; Selleri, C.; Della Porta, G.; Maffulli, N. Stem Cell and Macrophage Roles in Skeletal Muscle Regenerative Medicine. Int. J. Mol. Sci. 2021, 22, 10867. https://doi.org/10.3390/ ijms221910867

Academic Editor: Rasmus Kjøbsted

Received: 16 September 2021

Accepted: 6 October 2021

Published: 8 October 2021

Publisher's Note: MDPI stays neutral with regard to jurisdictional claims in published maps and institutional affiliations.

Copyright: (C) 2021 by the authors. Licensee MDPI, Basel, Switzerland. This article is an open access article distributed under the terms and conditions of the Creative Commons Attribution (CC BY) license (https:/ / creativecommons.org/licenses/by/ $4.0 /)$.

\begin{abstract}
In severe muscle injury, skeletal muscle tissue structure and functionality can be repaired through the involvement of several cell types, such as muscle stem cells, and innate immune responses. However, the exact mechanisms behind muscle tissue regeneration, homeostasis, and plasticity are still under investigation, and the discovery of pathways and cell types involved in muscle repair can open the way for novel therapeutic approaches, such as cell-based therapies involving stem cells and peripheral blood mononucleate cells. Indeed, peripheral cell infusions are a new therapy for muscle healing, likely because autologous peripheral blood infusion at the site of injury might enhance innate immune responses, especially those driven by macrophages. In this review, we summarize current knowledge on functions of stem cells and macrophages in skeletal muscle repairs and their roles as components of a promising cell-based therapies for muscle repair and regeneration.
\end{abstract}

Keywords: skeletal muscles; trauma; muscle healing and repair; stem cells; macrophages; immune cell role in tissue repair

\section{Introduction}

Skeletal muscle regeneration (SkMR) is the ability of injured muscles to functionally recover after traumas and is related to the intrinsic healing properties of injured tissue and to the type of injury based on the number of involved myofibers, muscle strength, and loss of contractility [1-3]. SkMR is a complex and finely regulated biological process involving different cellular populations, such as inflammatory cells and muscle stem cells, also known as satellite cells due to their spatial localization between connective tissue layers and sarcolemma (see also Figure 1) [4]. Satellite cells are quiescent in steady-state conditions; however, after injuries, they proliferate and differentiate to restore skeletal muscle physiology by sequential expression of specific transcription factors, such as Paired box 7 (Pax7) [5-8], followed by myogenic regulatory factors (MRFs), Myoblast determination protein $(M y o D)$, Myogenic factor 5 (Myf5), Myogenic factor 6 (Myf6), and finally Myogenin (Myog). MyoD and Myf5 are overexpressed during myoblast proliferation. While MyoD downregulation is replaced by Myf6 and Myog, triggering terminal differentiation of muscle progenitors towards elongated myocytes that fuse in multinucleated myotubes and mature in myofibers [9,10]. Fibro-adipogenic progenitors (FAPs) are important in SkMR and can 
negatively or positively influence muscle recovery depending on microenvironment composition [11,12]. For example, interleukin (IL)- $1 \beta$ inhibits FAP differentiation, while IL-4 has a pro-adipogenic effect; conversely, IL-15 stimulates FAP proliferation and prevents adipogenic differentiation [11,13]. Once activated, FAPs phagocyte necrotic debris, favor revascularization, release extracellular matrix (ECM) components, and promote matrix remodeling [14,15]. In chronic injuries, muscle tissue can be replaced with a mix of white adipocytes and fibrotic cells in a process called fatty degeneration, in which satellite cells can differentiate in both fibrocytes and adipocytes. When physiologic myogenic differentiation is impaired due to cell defects or pathological environmental changes, satellite cells switch to an alternative differentiation pathway [12,16-18]. In several in vitro and in vivo studies, successful muscle healing has been described when both stem cells or inflammatory cells are activated and participate in the regeneration processes [4]. The present review provides an update of stem cell and macrophage involvement in SkMR.

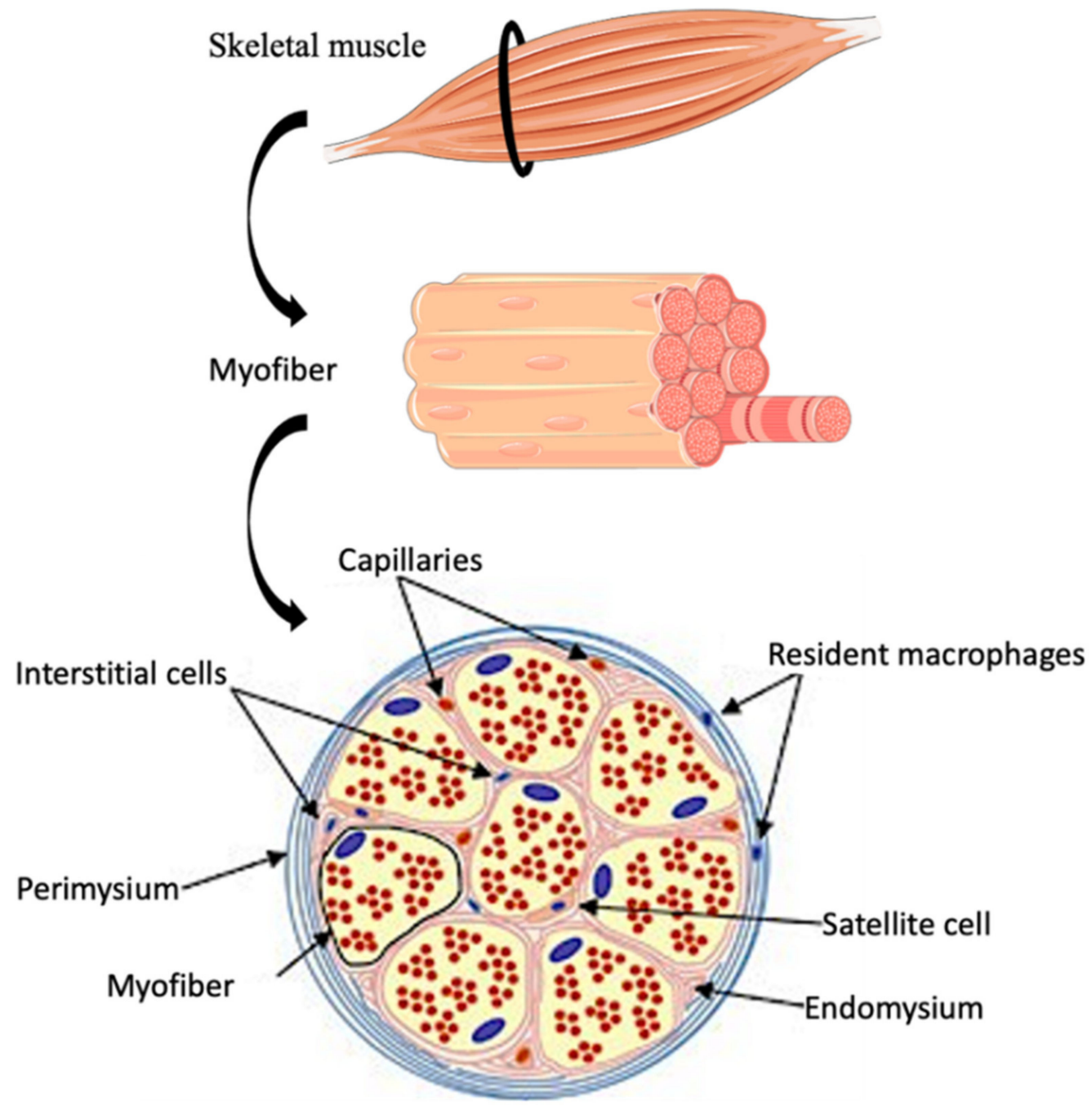

Figure 1. Schematic representation of the skeletal muscle structure. The connective tissue, called perimysium, surrounds groups of fibers, organized in multinucleated and longitudinally aligned bundles. Each single muscle cell, or myofiber, is surrounded by endomysium. Satellite cells are located between the connective tissue sheet and the myofiber plasma membrane, called sarcolemma.

\section{SkMR Biology}

The SkMR process can be schematically divided into three phases: (i) destruction, (ii) repair, and (iii) remodeling. In the first phase, the injured necrotic site is spatially defined within the contraction band composed of condensed cytoskeletal material and 
necrotic cells that release intracellular components from sarcolemma disruption into the bloodstream $[19,20]$. Injury also compromises blood vessel integrity leading to the activation of coagulation and complement cascades and causing muscle-resident mast celldependent inflammatory responses [21]. In the second phase, necrotic tissue is cleared by phagocytosis; then, during the third phase, myofiber regeneration begins and proceeds to the full recovery of skeletal muscle contractility and structure [19]. In all those phases, the immune system is strongly involved, influencing the rate of the healing process and scar tissue formation (Figure 2). After a few seconds post-injury, the complement system is rapidly activated by several damage-associated molecular patterns, such as the heat shock protein and high mobility group box-1 protein (HMGB1), released by injured myofibers [22,23]. Complement cascade activation results in the recruitment of immune cells at the site of injury and the start of inflammatory responses. Indeed, it has been reported that a deficiency of complement proteins, especially C3a, results in an impaired regeneration with smaller myofiber formation [22]. Leukocyte recruitment is directed by C5a at the injured site and by mast cells that rapidly release several pro-inflammatory mediators, such as tumor necrosis factor (TNF)- $\alpha$, histamine, IL-1, IL-6, platelet-activated-factor, and prostaglandins $[24,25]$. Resident neutrophils are also quickly activated after injury and release pro-inflammatory cytokines, including TNF- $\alpha$, IL- $1 \beta$, and interferon- $\gamma$ (IFN- $\gamma$ ). Within a few hours after the event, other neutrophils are recruited by secreted factors and contribute to oxidative and proteolytic modifications in the injured area [26,27]. Neutrophil depletion significantly decreases macrophage accumulation at the injured site, suggesting their fundamental role in monocyte recruitment [28].

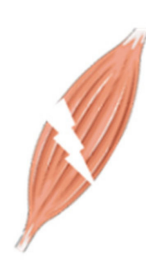

Injured Muscle

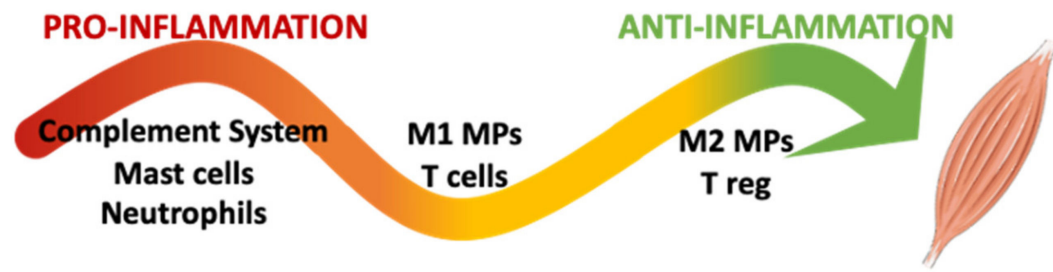

MUSCLE REGENERATION PROGRESSION

Healthy muscle

Figure 2. Schematic representation of the events succession related to immune cells during the SkMR. In early phase, the innate immune response activates the complement system, mast cells, and neutrophils. All these cells recruit monocytes at the injured site that mature in macrophages (MPs) with first a pro-inflammatory phenotype (M1-MPs) and then an anti-inflammatory phenotype (M2-MPs). These cells cooperate with local stem cells to promote tissue repair and regeneration.

In severe injuries, such as muscle tears, endogenous muscle repair capacity is not sufficient for complete muscle recovery, and clinical management of these conditions remains one of the most challenging in the orthopedic field. In these cases, therapeutic approaches include cell-based therapies using stem cells of myogenic and non-myogenic origins (see Table 1) [29].

In more detail, stem cell therapy (SCT) can employ satellite cells because they can repopulate the stem cell niche increasing the regenerative muscle potential and its contractility [30-34]. Moreover, muscle-derived stem cells (MDSCs), not-terminally differentiated satellite cell precursors, have mesodermal tissue commitment potential and elevate engraftment rates after transplantation $[35,36]$. However, the efficacy of SCT in SkMR is still limited because satellite cells and MDSCs are rare populations (2-7\%), and their isolation and harvesting are extremely challenging [29]. For these reasons, mesenchymal stem cells (MSCs) are often preferred, even though they are not of myogenic origin. MSCs have a broad differentiation potential including bone [37], cartilage [38], tendon [39-41], and muscle [42], and can be mainly isolated from several tissues, such as bone marrow (BM) and adipose tissue [43]. Recently, also MSCs from the umbilical cord seemed an interesting cell source for musculoskeletal tissue engineering [40,41]. 
In particular, BM-derived MSC (BM-MSC) therapy can significantly improve muscle contraction strength, as well as adipose tissue-derived MSC (ADSC) infusion, which can increase the number of new regenerated myofibers at the injury site [44-47]. Moreover, BMMSCs can downregulate pro-inflammatory cytokines while upregulating anti-inflammatory mediators reducing fibrosis evolution through transforming growth factor- $\beta$ (TGF- $\beta$ ) signaling and related collagen deposition [48]. The failure of BM-MSC engraftment is associated with massive and prolonged leukocyte infiltration in the muscle, reduced myofiber regeneration, increased cell necrosis, and elevated pro-inflammatory cytokine secretion [49].

Table 1. Potential SC therapies for skeletal muscle regeneration. In vivo studies.

\begin{tabular}{|c|c|c|c|c|c|}
\hline Animals & Transplanted SCs & Injury & Muscle & Results & Ref \\
\hline Mdx mice & MuSCs & Notexin injection & Tibialis anterior & Self-renewal of host SC niche & [29] \\
\hline Mice & MuSCs & Notexin injection & Tibialis anterior & High engraftment percentage & {$[30]$} \\
\hline Mdx mice & MuSCs & Cardiotoxin injection & Tibialis anterior & Muscle contractility & {$[32]$} \\
\hline Mice & Human MDSCs & Cryolesion & Tibialis anterior & Fusion with host myofibers & [34] \\
\hline SD rats & Autologous MSCs & Open crush trauma & Soleus muscle & Muscle force improvement & {$[44]$} \\
\hline SD rats & Autologous BM-MSCs & Open crush trauma & Soleus muscle & Contraction force increase & [45] \\
\hline SD rats & Autologous BM-MSCs & Open crush trauma & Soleus muscle & Muscle force improvement & [46] \\
\hline Wistar rats & Autologous ADSCs & Surgical laceration & Soleus muscle & $\begin{array}{l}\text { Regenerating myofibers } \\
\text { increase }\end{array}$ & [47] \\
\hline Wistar rats & Autologous BM-MSCs & Scalpel laceration & Adductor brevis & $\begin{array}{l}\text { Regenerating myofibers } \\
\text { increase }\end{array}$ & [48] \\
\hline Mice & BM-MSCs & Contusion & Gastrocnemius muscle & $\begin{array}{l}\text { Muscle fibrosis and } \\
\text { inflammation }\end{array}$ & [49] \\
\hline
\end{tabular}

SC, stem cell, Mdx mice, dystrophin-deficient mice, MuSCs, muscle satellite stem cells, MDSCs, muscle-derived stem cells, SD, Sprague Dawley rat, MSCs, mesenchymal stem cells, BM, bone marrow, ADSCs, adipose tissue-derived stem cells.

\section{Macrophages and Muscle Healing}

Macrophages can polarize toward two different phenotypes based on acting stimuli (Figure 3): pro-inflammatory (M1-MPs) and anti-inflammatory (M2-MPs) cells. T helper (Th)1-related cytokines, such as IFN- $\gamma$ and TNF- $\alpha$, or lipopolysaccharide (LPS), induce M1-MP differentiation, while Th2 cytokines (e.g., IL-4 and IL-13) or IL-10 and IL-33 switch macrophage differentiation toward the M2-MP phenotype [50,51]. M1-MPs express CD68 at a high level that mediates the activation of phagocytosis and pro-inflammatory cytokine secretion; conversely, M2-MPs, positive for CD163 and CD206 and negative for CD68, promote anti-inflammatory cytokine release [51].

The in vivo M1/M2 dichotomy is more a dynamic process rather than an on/off differentiation as described in vitro experiments. Indeed, in vivo, macrophages can easily switch from one functional phenotype to another in response to several local signals: M1-MPs accumulate at the injured area within the $24 \mathrm{~h}$, rapidly decreased, and switched to M2-MPs within two/four days [52-54]. Simultaneously, tissue-resident macrophages recruit neutrophils through chemoattractant proteins, such as monocyte chemoattractant protein 1 (MCP-1) [55]. Satellite cells also contribute to monocyte recruitment at the injury site via macrophage-derived chemokine (MDC) in the earliest phases of MCP-1 during the late stages of myogenic differentiation [56]. At early regeneration stages, neutrophils amplify M1-MP-mediated phagocytosis through oxidative modification of low-density lipoproteins that bind and activate CD68 [57]. After clearance of debris at the injured site by macrophages, M1-MPs secrete TGF- $\beta$, responsible for phagocytosis rate reduction [58]. The urokinase (uPA)-mediated plasminogen activation system is involved in various biological processes, including inflammation, wound healing, and muscle regeneration [59]. During regeneration, uPA-expressing macrophages promote effective muscle regeneration through ECM regulation and remodeling, as well as favoring monocyte migration at the injured site [59-61]. 

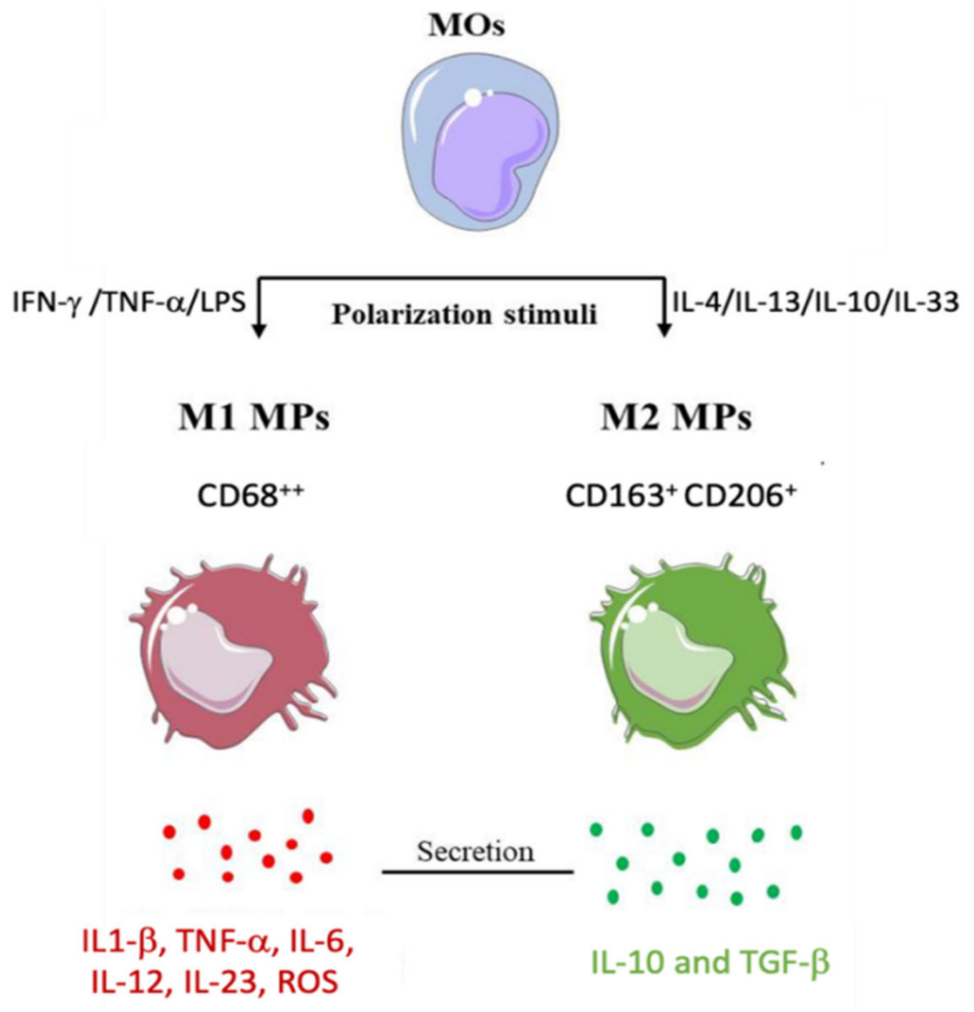

Figure 3. Schematic representation of macrophages polarization protocols adopted in vitro. Monocytes (MOs) evolve towards the pro-inflammatory (M1) macrophages (MPs) after T-helper 1 (Th1) response cytokines or microbial stimuli, such as lipopolysaccharide (LPS); conversely, they evolve towards anti-inflammatory (M2) macrophages (MPs) after T-helper 2 (Th2) cytokines. M1-MPs are characterized by a high expression of CD68 surface markers, the secretion of pro-inflammatory cytokines and reactive oxygen species (ROS). M2-MPs are characterized by elevated levels of CD163 and CD206 and low levels of CD68; they also secrete anti-inflammatory cytokines. Abbreviations: IFN- $\gamma$, Interferon- $\gamma$, TNF- $\alpha$, Tumor Necrosis Factor- $\alpha$, IL, Interleukin, TGF- $\beta$, Transforming growth factor- $\beta$.

\section{Macrophages and Muscle Healing: In Vivo Evidence}

The pivotal role of macrophages during SkMR has been largely confirmed in vivo mouse models (Table 2). Chemokine C-X3-C motif receptor $(\mathrm{CX} 3 \mathrm{CR})^{\mathrm{lo}} / \mathrm{Ly}-6 \mathrm{C}^{+}$monocytes/macrophages are the first cell population invading the site within 90 min after injury reaching a peak at $24 \mathrm{~h}$. They produce a high amount of IL-1 $\beta$ and TNF- $\alpha$ during the first two-three days then switching to CX3CR ${ }^{\text {hi }} /$ Ly- $6 C^{-}$cells expressing IL-10 and TGF- $\beta 1$, characterizing the regenerative phase [58]. CX3CR ${ }^{10} / \mathrm{Ly}-6 \mathrm{C}^{+}$monocytes/macrophages mediate phagocytosis of necrotic myofibers in the first two days after injury, while $\mathrm{Ly}-6 \mathrm{C}^{-}$ macrophages surround the new regenerating myofibers between four-eight days after the event $[62,63]$. An earlier start of anti-inflammatory responses is associated with inefficient regeneration, as described in mitogen-activated protein kinase phosphatase-1 (MKP-1), a regulator of MAPK activation, deficient mouse model. In MKP-1 ${ }^{-1-}$ mice, macrophages are still able to accumulate at the injury site; however, inflammation persists after 10 days post-injury with a constant expression of myogenic markers in satellite cells, and myofibers are of smaller size and centrally nucleated. At the injured site, both $\mathrm{Ly}-6 \mathrm{C}^{+}$and $\mathrm{Ly}-6 \mathrm{C}^{-}$ macrophages express high levels of anti-inflammatory cytokines on day three, suggesting a premature activation of anti-inflammatory responses [64]. Protein kinase AMP-activated catalytic subunit $\alpha-1(\mathrm{AMPK} \alpha-1)$ plays an important role in macrophage phenotype transition. In AMPK $\alpha-1^{-1-}$ mice, M1-MPs remain constantly increased, while M2-MP frequency does not change during muscle regeneration, resulting in impaired SkMR [65]. 
The role of macrophages in SkMR has been also investigated by blocking cell recruitment at the injury site and by showing the kinetics of cell recruitment on correct muscle regeneration. Macrophages are important in the first and early phase of inflammation because a deficient accumulation at the injured site results in smaller regenerating myofibers and in fatty tissue accumulation [66]. High frequency of M1-MPs at the injured site is favored by monocytes; however, monocyte depletion does not abolish macrophage accumulation likely due to intrinsic M1-MP proliferative capacity [67]. In this case, necrotic myofibers are not efficiently cleared and persist after nine days post-injury with fatty degeneration [68]. $\mathrm{C}-\mathrm{C}$ chemokine receptor type 2 (CCR2), the natural ligand of MCP-1, is not expressed in healthy muscle while is released early during regeneration and is essential for macrophage recruitment [69]. In CCR2 ${ }^{-/-}$mice, mononuclear cell infiltration (represented mostly by neutrophils) is minimal in early phases and necrotic myofibers are still present after twenty days with a consistent accumulation of adipocytes [70]. Moreover, lower macrophage levels in the injured area are associated with reduced insulin-like growth factor 1 and impaired muscle regeneration [71]. Similarly, $M C P 1^{-/-}$mice show a markedly reduced inflammation and macrophage accumulation at day three post-injury, with the presence of necrotic myofibers at day seven and small-sized regenerating myofibers detectable only at day twenty [72,73]. SkMR can be favored by macrophage injections, especially using in vitro polarized M1-MPs, within $24 \mathrm{~h}$ post injury resulting in significant improvement of muscle function with larger myofibers. The efficacy of macrophage injection is related to a faster clearance of necrotic debris that allows a rapid replacement of newly myofibers with faster transition from M1 to M2 [74].

Table 2. Macrophages and skeletal muscle regeneration. In vivo studies.

\begin{tabular}{|c|c|c|c|c|c|}
\hline Animals & Injury & Muscle & Depletion Strategy & Results & Ref \\
\hline Mice & Notexin & Tibialis anterior & Diphtheria toxin & M1-MPs, switching in M2-MPs & [58] \\
\hline Mice & Cardiotoxin & Tibialis anterior & $1+-$ & M1-MPs, switching in M2-MPs & [62] \\
\hline Mice & Laceration & Gastrocnemius & - & M1/M2 phenotype-like classification & [63] \\
\hline Mice & Cardiotoxin & Gastrocnemius & - & Phenotype transition & {$[64]$} \\
\hline Mouse & Cardiotoxin & Tibialis anterior & - & $\mathrm{AMPK} \alpha 1$ involved in $\mathrm{M} 2$ polarization & [65] \\
\hline Mice & Cardiotoxin & Tibialis anterior & Diphtheria toxin & SkMR impairment & [66] \\
\hline Wistar rats & Bupivacaine & Tibialis anterior & $\begin{array}{c}\mathrm{Cl}_{2} \mathrm{MDP} \text { liposome \& } \\
\gamma \text {-rays }\end{array}$ & MP number decrease & [67] \\
\hline Mice & Cooled probe & Tibialis anterior & Clodronate liposomes & Regeneration impairment & [68] \\
\hline Mice & Cooled probe & Tibialis anterior & - & Muscle strength recovery impairment & [69] \\
\hline Mice & FAE & $\begin{array}{l}\text { Hindlimb } \\
\text { muscles }\end{array}$ & - & Necrotic myofiber persistence & [70] \\
\hline Mice & Barium Chloride & Quadriceps & - & Necrotic myofiber persistence & [71] \\
\hline Mice & Barium Chloride & Quadriceps & - & CCL2 for immune cell recruitment & [72] \\
\hline Mice & FAE & $\begin{array}{l}\text { Hindlimb } \\
\text { muscles }\end{array}$ & - & $\begin{array}{l}\text { Necrotic myofiber persistence } \\
\text { fat accumulation occurrence }\end{array}$ & [73] \\
\hline Mice & TK-I/R & Gastrocnemius & - & $\begin{array}{l}\text { Muscle functionalities recover by } \\
\text { M1-MPs }\end{array}$ & [74] \\
\hline
\end{tabular}

MPs, macrophages, MKP-1, mitogen-activated protein kinase phosphatase-1, AMPK $\alpha 1$, protein kinase AMP-activated catalytic subunit $\alpha-1$, $\mathrm{Cl}_{2} \mathrm{MDP}$, dichloromethylene diphosphonate, $\mathrm{FAE}$, femoral artery excision, $\mathrm{CCl}$, $\mathrm{C}-\mathrm{C}$ motif chemokine ligand 2, $\mathrm{BaCl}_{2}$, barium chloride, TK-I/R, tourniquet-induced ischemia/reperfusion injury.

\section{Macrophages and Myogenic Precursors: A Functional Crosstalk}

Biological mechanisms underlying the complex crosstalk between myogenic precursors and macrophages at the injured site remain unclear [56]; a summary of possible functional crosstalks is summarized in Table 3. Macrophages provide survival and mitogenic stimuli directed to myogenic precursor growth. During SkMR, a specific injury-located MP group creates a transient niche for satellite cell proliferation by releasing mitogenic molecules, such as cytokine nicotinamide phosphoribosyltransferase whose receptors are on satellite cells (C-C motif chemokine receptor type 5, CCR5) [75]. The high satellite cell proliferating rate is due to activation of anti-apoptotic signaling pathways, such as reduced 
activation of pro-apoptotic caspase-3 and increased anti-apoptotic Bcl-2 protein expression [56,76]. In detail, four cell-cell anti-apoptotic pathways are constitutively expressed by myogenic precursors and their ligands by macrophages: (i) vascular cell adhesion molecule 1 (VCAM-1)/very late antigen 4 (VLA-4); (ii) intercellular cell adhesion molecule 1 (ICAM-1)/leukocyte function-associated molecule 1 (LFA-1); (iii) platelet-endothelial cell adhesion molecule homophilic 1 (PECAM-1); (iv) C-X3-C motif chemokine ligand 1 (CX3CL1) binding to C-X2-C motif receptor 1 (CX2CR1) [76]. VCAM-1 is considered a specific marker for myogenic precursors. During myogenesis, VCAM-1/VLA-4 interaction occurs with the expression of VCAM-1 by myogenic progenitors and of VLA-4 by immune cells [77], as summarized in Figure 4.

\section{Myogenic precursors}

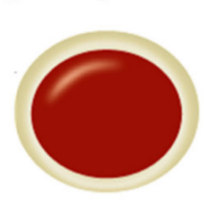

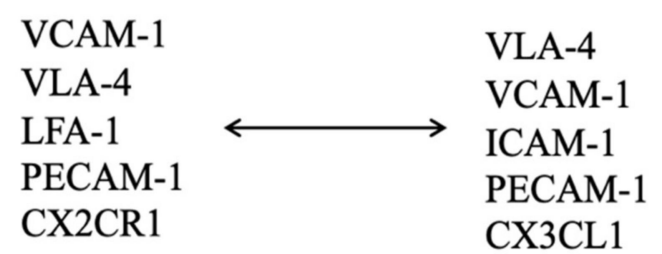

\section{Macrophages}

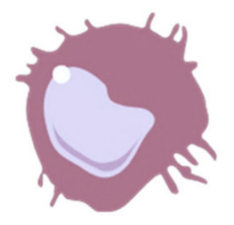

Figure 4. Schematic representation of myogenic precursors and macrophages crosstalk. A functional crosstalk is established between myogenic precursors and macrophages to promote cells survival and proliferation during skeletal muscle healing. Macrophages expressed the vascular cell adhesion molecule 1 (VCAM-1), intercellular cell adhesion molecule binding 1 (ICAM-1), platelet-endothelial cell adhesion molecule homophilic (PECAM-1) and C-X3-C motif chemokine ligand 1 (CX3CL1); all these signals interact with their counter-ligands on myogenic precursors: very late antigen 4 (VLA-4), leukocyte function-associated molecule 1 (LFA-1), platelet-endothelial cell adhesion molecule homophilic (PECAM-1), and C-X2-C motif receptor 1 (CX2CR1), respectively. Moreover, myogenic precursors express VCMA-1 that interact with VLA-4 of immune cells.

Table 3. Macrophages and myogenic cells precursors: a functional crosstalk. In vitro and in vivo studies.

\begin{tabular}{|c|c|c|c|c|c|}
\hline & \multicolumn{3}{|c|}{ Cell Culture } & Results & Ref \\
\hline \multirow{3}{*}{ In vitro } & \multicolumn{3}{|c|}{ MPCs/MPs co-culture } & MPs rescue MPCs from spontaneous apoptosis & [76] \\
\hline & \multicolumn{3}{|c|}{ MPCs/MPs co-culture } & $\begin{array}{c}\text { Direct contacts between MPs on MPCs are } \\
\text { not required }\end{array}$ & [78] \\
\hline & Graft & Muscle & Injury & Results & Ref \\
\hline \multirow{3}{*}{ In vivo } & Mice & Tibialis anterior & Notexin injection & $\begin{array}{c}\text { MPs and MPCs anti-apoptotic contacts } \\
\text { establishment }\end{array}$ & [76] \\
\hline & Human & Vastus lateralis & $\begin{array}{l}\text { Electrically } \\
\text { stimulation }\end{array}$ & $\begin{array}{l}\text { Different spatial position of MPs in } \\
\text { regenerating areas }\end{array}$ & [78] \\
\hline & Wistar rats & Tibialis anterior & Surgery ablation & MPs conditioned medium enhances SkMR & [79] \\
\hline
\end{tabular}

MPCs, myogenic precursors cells, MPs, macrophages, SkMR, Skeletal muscle regeneration

M1-MPs inhibit myogenic precursors fusion, while M2-MPs stimulate myotube formation even without direct cell contact [78]. Moreover, the stage of the muscle healing process influences the effects of macrophages on myogenic precursors. Macrophages expressing pro-inflammatory markers are abundant in regenerating areas negative for $M y o g$ (a transcription factor expressed only in differentiated myogenic cells) suggesting different associations based on proliferation or differentiation of myogenic precursors $[78,79]$.

\section{Cytokines and Muscle Healing}

Cytokines are also involved in the complex crosstalk between myogenic precursors and macrophages, as described below and summarized in Tables 4 and 5, and Figure 5). 


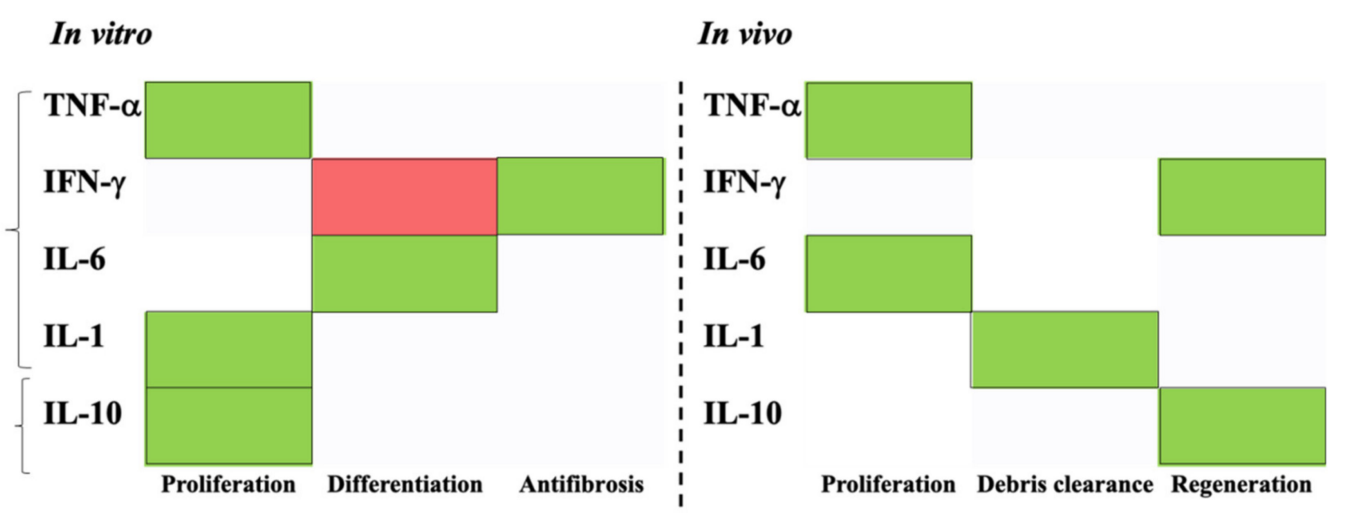

Figure 5. Schematic representation of cytokines contribution documented in both in vitro and in vivo studies (green box: promotion; red box: inhibition). Pro-inflammatory and anti-inflammatory cytokines showed an important contribution during skeletal muscle regeneration: in vitro, they mainly activated myoblasts proliferation and differentiation (except for INF- $\gamma$ ); in vivo, cytokines expression, promoted tissue clearance and its regeneration. Abbreviations: TNF- $\alpha$, Tumor Necrosis factor- $\alpha$, IFN- $\gamma$, Interferon- $\gamma$, IL, Interleukin.

\section{1. $T N F-\alpha$}

TNF- $\alpha$ is transiently upregulated in myoblasts within 3 to $48 \mathrm{~h}$ post differentiation induction in a dose-dependent manner: myogenesis is stimulated at low TNF- $\alpha$ concentrations, while is inhibited at high concentrations $[80,81]$. TNF- $\alpha$ has mitogenic and chemotactic effects on proliferating primary rat myoblasts $[82,83]$. Proliferating myoblasts fuse each other's within 4 days in absence of TNF- $\alpha$, whereas TNF- $\alpha$ treatments completely inhibit myotube formation and reduce Myog expression. In healthy muscles, TNF- $\alpha$ expression is constitutively low; however, after injury, its expression increases within $5 \mathrm{~h}$, reaching a peak at $24 \mathrm{~h}$, and then gradually decreases. In TNF- $\alpha$ receptor double-knockout mice, p38 MAPK expression diminishes together with MyoD-1, a proliferation marker, in TNF- $\alpha$ deficient mice [84]. Moreover, this proliferating effect is exerted on satellite cells after in vivo TNF- $\alpha$ intraperitoneal injection [82], while Myog is reduced confirming differentiation inhibition of this cytokine on myoblasts [85]. TNF- $\alpha$ could be also involved in muscle strength recovery, likely through modulation of muscle regulatory gene expression, such as $M y o D[80,84]$.

\subsection{IFN- $\gamma$}

IFN- $\gamma$, a pro-inflammatory cytokine, favors myoblast proliferation, prevents fibrotic events in SkMR, and is expressed by proliferating myoblasts while not by differentiated cells. IFN- $\gamma$ stimulation impairs myoblast fusion and differentiation gene expression, likely through inhibition of Myog expression by Class II Major Histocompatibility Complex transactivator (CIITA). However, this inhibition is reversible as CIITA is quickly downregulated, and muscle-specific genes upregulated [86,87]. IFN- $\gamma$ also acts as an antifibrotic agent by reducing TGF $\beta-1$ expression [88]. IFN- $\gamma$ expression is at basal levels in healthy muscles, while increases after injury, peaking at day five post-injury corresponding to immune cell and myoblast infiltration. Moreover, IFN- $\gamma$ is important in macrophage recruitment, induction of regenerating myofibers, and connective tissue formation [87,88].

\subsection{IL-6}

IL-6 is an important mediator in SkMR and is highly produced by myogenic cells and macrophages. IL-6 is necessary for stimulation of myoblast proliferation, and its levels progressively decrease with clearance of necrotic cells $[89,90]$. Myoblast proliferation is favored by low and medium IL-6 concentrations, while high concentrations induce myogenic differentiation. In addition, IL-6 shows time-dependent effects on primary cultures of human myoblasts: $M y o D$ expression increases after $24 \mathrm{~h}$, with subsequent increase of Myog at $48 \mathrm{~h}$ [91]. IL-6 also exerts a chemoattractant role for macrophage 
recruitment at the injured site [90]. In healthy muscles, IL-6 is not expressed, while increases at one day post-injury, and starts to decrease after five days from the event. In $\mathrm{IL}-6^{-/-}$mice, the regenerative rate is lower because proteins related to myogenesis are poorly expressed and newly formed myofibers are smaller with interstitial fibrosis, and also because satellite cells and myoblasts show a lower proliferation and migration rate $[89,90]$.

\subsection{IL-1}

IL-1 is a pro-inflammatory cytokine involved in muscle growth and regeneration probably enhancing clearance of necrotic fibers. In myoblasts, IL-1 $\beta$, an IL-1 isoform, induces cyclin A and B1, master regulators of G1/S and G2/M transition, respectively. Between three to five days post-differentiation induction, IL- $1 \beta$ enhances muscle proteins synthesis, such as myosin heavy chain, and increases fusion index [92]. Prolonged IL-1 exposure induces muscle catabolism in a time-dependent manner with reduction of myotube width and sarcomeric actin levels [93]. Myoblasts from IL-1 knockout mice show a significantly slower growth compared to wild type. The proliferation rate can be restored with exogenous IL-1 $\beta$, but not with IL-1 $\alpha$ [94]. Moreover, inflammatory cells are fewer, necrotic myofibers are not efficiently cleared, and myogenic differentiation marker expression is markedly reduced in IL-1 deficient mice compared to controls [94]. IL-1 $\beta$ expression reaches a peak at two-three days after injury and remains high up to 5 days post-event [95].

\section{5. $I L-10$}

IL-10 is the main anti-inflammatory cytokine in SkMR and is essential for regeneration of new myofibers. IL-10 treatment does not affect myoblast proliferation, while activated macrophages and induce proliferation and differentiation of myoblasts, without affecting $M y o D$ and Myog gene expression along the early differentiation stage [54]. IL-10 expression is upregulated three days post-injury reaching the maximum after seven days [96]. In $\mathrm{IL}_{10}{ }^{-/-}$mice, injured myofibers are not efficiently cleared resulting in reduced centronucleated myofibers that also show smaller sizes compared to control. Moreover, in IL10 ${ }^{-/-}$mice, M1/M2 transition is delayed, resulting in amplification of Th1 responses and increased Myog levels, likely due to indirect effects of other cytokines [54].

Table 4. Cytokines and skeletal muscle regeneration. In vitro studies.

\begin{tabular}{|c|c|c|}
\hline Cell Culture & Results & Ref \\
\hline $\mathrm{C} 2 \mathrm{C} 12$ & After differentiation induction, TNF- $\alpha$ expression increases & [80] \\
\hline Murine myoblasts & Myoblast migration stimulation & {$[82]$} \\
\hline Murine myoblasts & Myoblast migration induction & [83] \\
\hline $\mathrm{C} 2 \mathrm{C} 12$ & Inhibition of myoblast differentiation into myotubes & [81] \\
\hline $\mathrm{C} 2 \mathrm{C} 12$, Primary myoblasts & Inhibition of myoblast differentiation & {$[86]$} \\
\hline $\mathrm{C} 2 \mathrm{C} 12$ & Reduction of myoblast proliferation & [87] \\
\hline Muscle-derived fibroblasts $\mathrm{C} 2 \mathrm{C} 12$ & Decrease TGF $\beta-1$ expression & {$[88]$} \\
\hline Mice MPs, C2C12 & Induction of myoblast proliferation & {$[90]$} \\
\hline $\mathrm{C} 2 \mathrm{C} 12$, Primary human myoblasts & Proliferation and differentiation due to different IL- 6 concentrations & [91] \\
\hline $\mathrm{C} 2 \mathrm{C} 12$ & Increase of myoblast fusion index & [92] \\
\hline $\mathrm{C} 2 \mathrm{C} 12$ & IL-1 induces muscle catabolic pathway & [93] \\
\hline Mice satellite cells & IL-1 induces cell proliferation & [94] \\
\hline Mice MPs, C2C12 & IL-10 activated macrophages promote myoblasts proliferation & [54] \\
\hline
\end{tabular}

TNF- $\alpha$, Tumor Necrosis factor- $\alpha$, TGF- $\beta 1$, Transforming growth factor- $\beta 1$, IL, Interleukin, MPs, macrophages. 
Table 5. Cytokines and skeletal muscle regeneration. In vivo studies.

\begin{tabular}{|c|c|c|c|c|c|}
\hline Animals & Injury & Injection & Muscle & Results & Ref \\
\hline Mice & Cooled probe & - & Tibialis anterior & $\begin{array}{l}\text { TNF- } \alpha \text { involved in muscle } \\
\text { strength recovery }\end{array}$ & [84] \\
\hline Mice & - & TNF- $\alpha$ & Soleus Diaphragm & $\begin{array}{l}\text { TNF- } \alpha \text { stimulates satellite cell } \\
\text { proliferation }\end{array}$ & [82] \\
\hline Mice & HS/RL & TNF- $\alpha$ & $\begin{array}{c}\text { Soleus } \\
\text { Gastrocnemius }\end{array}$ & Decrease of Myog expression & [85] \\
\hline Mice & Cardiotoxin & $\begin{array}{lll}- & \\
& - & \end{array}$ & Soleus & SkMR impairment & [80] \\
\hline Mice & Cardiotoxin & $\begin{array}{l}\text { IFN- } \gamma \mathrm{R} \text { blocking } \\
\text { antibody }\end{array}$ & $\begin{array}{l}\text { Extensor digitorum } \\
\text { longus Tibialis anterior }\end{array}$ & $\begin{array}{l}\text { Reduction of regenerating } \\
\text { myofiber formation }\end{array}$ & [87] \\
\hline Mice & Laceration & IFN- $\gamma$ & Gastrocnemius & Minor fibrosis rate & [88] \\
\hline Mice & Cardiotoxin & IL-6 & $\begin{array}{l}\text { Tibialis anterior } \\
\text { Gastrocnemius }\end{array}$ & Inhibition of proliferating cells & {$[90]$} \\
\hline Mice & Overloading & - & $\begin{array}{l}\text { Soleus } \\
\text { Plantaris muscles }\end{array}$ & $\begin{array}{l}\text { Stimulation of migration and } \\
\text { proliferation }\end{array}$ & [89] \\
\hline Mice & $\mathrm{BaCl}_{2}$ injection & - & Tibialis anterior & Early increase of IL- $1 \beta$ expression & [95] \\
\hline Mice & Cardiotoxin & - & Tibialis anterior & $\begin{array}{l}\text { Reduction of inflammatory cells } \\
\text { infiltration }\end{array}$ & {$[94]$} \\
\hline $\begin{array}{l}\text { Mice } \\
\text { Mice }\end{array}$ & $\begin{array}{l}\text { Contusion } \\
\text { HU/RL }\end{array}$ & $\begin{array}{l}- \\
-\end{array}$ & $\begin{array}{l}\text { Gastrocnemius } \\
\text { Soleus }\end{array}$ & $\begin{array}{l}\text { IL-10 peak at } 7 \text { days } \\
\text { SkMR impairment }\end{array}$ & $\begin{array}{l}{[96]} \\
{[54]}\end{array}$ \\
\hline Mice & FAE & - & Hindlimb muscles & $\begin{array}{l}\text { Necrotic myofibers persistence; } \\
\text { fat accumulation }\end{array}$ & {$[73]$} \\
\hline Mice & TK-I/R & - & Gastrocnemius & $\begin{array}{l}\text { Recovery of muscle functionality } \\
\text { by M1-MPs delivery }\end{array}$ & {$[74]$} \\
\hline
\end{tabular}

TNF- $\alpha$, Tumor Necrosis factor- $\alpha$, Myog, Myogenin, SkMR, Skeletal muscle regeneration, IL, Interleukin, HS/RL, hind limb suspension/reloading, IFN- $\gamma \mathrm{R}$, interferon- $\gamma$ (IFN- $\gamma$ ) receptor, $\mathrm{BaCl}$, barium chloride, HU/RL, hind limb unloading/reloading, FAE, femoral artery excision, TK-I/R, tourniquet-induced ischemia/reperfusion injury, MPs, macrophages.

\section{Conclusions and Perspectives}

When skeletal muscle regeneration remains unresolved, cell therapy could represent a valid clinical approach. Myogenic stem cells provide excellent results when infused at optimal concentrations; however, myogenic stem cells are rare and their isolation is still challenging [29]. For these reasons, stem cell therapy has moved towards other types of (mesenchymal) stem cells, harvested from various adult human tissues, such as bone marrow and adipose tissue. Similar to myogenic stem cells, also mesenchymal stem cells are difficult to obtain in optimal amounts for transplant success $[97,98]$. Stem cell sampling, harvesting, and preparation is even more difficult in patients with pathologies [99] worsening autologous transplantation outcomes. Stem cells are active in muscle repair because of their immunomodulatory effects, many of these still undiscovered, and because of immune system recruitment through cellular and soluble factor release.

On the other hand, macrophages seem to be the principal immune cell involved in muscle regeneration by first favoring inflammation and clearance of injured area from necrotic debris; and then by enhancing inflammation resolution and forcing myogenic precursor cells to differentiate in regenerating myofibers. However, the complex crosstalk between macrophages and myogenic cells is still under investigation and it is still unclear if cell-cell contacts or paracrine signals induced by soluble factors are fundamental in restoring skeletal muscle physiology. Indeed, released cytokines exert a fine regulation of the muscle healing process, as pro-inflammatory molecules enhance myogenic precursor proliferation whereas anti-inflammatory ones influence macrophage transition towards an anti-inflammatory phenotype, damping inflammation. Several in vivo studies suggest that the presence of M1-MPs can accelerate clearance of necrotic debris and promote the resolution of inflammation when switched in M2-MPs. In vitro and in vivo studies -with some differences related to microenvironment composition- strongly suggest that macrophages are the main actors of muscle regeneration and that the lack of this cell subset severely impairs all steps of muscle healing.

Available literature indicates the predominant role of the immune system in muscle regeneration that requires further and deeper investigations also because of the therapeutic potential of targeting or modulating immune cells for facilitating muscle repair. For example, peripheral blood mononuclear cells are already described as a valid alternative source 
for cell therapy, as they are easier to sampling and isolate $[49,90]$. Moreover, peripheral blood cell therapy can dramatically increase the number of regenerating myofibers at seven days after autologous transplantation by using a simple whole-blood gravity filtration device such as the device largely used in patients with critical limb ischemia and ineligible for surgical revascularization; in those cases, the treatment allowed a significant reduction in amputation rate [100-102]. This clinical observation is relevant to supports the role of the immune system in tissue regeneration and healing; indeed, even if further studies are required to understand the complex cellular cross-talk involved in these processes, it may open encouraging perspectives for clinical use of peripheral blood cells in skeletal muscle regeneration.

Author Contributions: P.S. conceptualization, data curation, writing—original draft preparation; L.R. methodology, visualization; V.G. methodology, visualization; E.C. visualization, A.A.P. visualization; C.S. visualization; G.D.P. conceptualization, data curation, supervision, project administration, writing-review and editing; N.M. supervision, funding acquisition. All authors validated the data and reviewed the manuscript. All authors have read and agreed to the published version of the manuscript.

Funding: Athena Srl 139: Viale Europa-50126 Firenze by: (i) research contract entitled "The design and implementation of an 3D bioengineered model for study on skeletal muscle regeneration and inflammation processes. Year 2020-2021; (ii) PhD grant Cycle XXXV in Translational Medicine at Dept. of medicine, Surgery and Dentistry, University of Salerno entitled: "Skeletal muscle regeneration modulated by inflammation: an in vitro study on a 3D bioengineered system".

Institutional Review Board Statement: Not Applicable.

Informed Consent Statement: Not Applicable.

Data Availability Statement: Not Applicable.

Conflicts of Interest: The authors declare no conflict of interest and the funders had no role in the design of the study; in the collection, analyses, or interpretation of data; in the writing of the manuscript, or in the decision to publish the results.

\section{References}

1. Frontera, W.R.; Ochala, J. Skeletal Muscle: A Brief Review of Structure and Function. Calcif. Tissue Int. 2015, 96, 183-195. [CrossRef] [PubMed]

2. Fernandes, T.L.; Pedrinelli, A.; Hernandez, A.J. Muscle injury-Physiopathology, diagnosis, treatment and clinical presentation. Rev. Bras. Ortop. Engl. Ed. 2011, 46, 247-255. [CrossRef]

3. Shin, E.H.; Caterson, E.J.; Jackson, W.M.; Nesti, L.J. Quality of Healing: Defining, Quantifying, and Enhancing Skeletal Muscle Healing: Muscle Injury Repair and Regeneration. Wound Repair Regen. 2014, 22, 18-24. [CrossRef] [PubMed]

4. Karalaki, M.; Fili, S.; Philippou, A.; Koutsilieris, M. Muscle Regeneration: Cellular and Molecular Events. Vivo Athens Greece 2009, 23, 779-796.

5. Yin, H.; Price, F.; Rudnicki, M.A. Satellite Cells and the Muscle Stem Cell Niche. Physiol. Rev. 2013, 93, 23-67. [CrossRef]

6. Oustanina, S.; Hause, G.; Braun, T. Pax7 Directs Postnatal Renewal and Propagation of Myogenic Satellite Cells but Not Their Specification. EMBO J. 2004, 23, 3430-3439. [CrossRef]

7. Kuang, S.; Chargé, S.B.; Seale, P.; Huh, M.; Rudnicki, M.A. Distinct Roles for Pax7 and Pax3 in Adult Regenerative Myogenesis. J. Cell Biol. 2006, 172, 103-113. [CrossRef]

8. Von Maltzahn, J.; Jones, A.E.; Parks, R.J.; Rudnicki, M.A. Pax7 Is Critical for the Normal Function of Satellite Cells in Adult Skeletal Muscle. Proc. Natl. Acad. Sci. USA 2013, 110, 16474-16479. [CrossRef]

9. Schmidt, M.; Schüler, S.C.; Hüttner, S.S.; von Eyss, B.; von Maltzahn, J. Adult Stem Cells at Work: Regenerating Skeletal Muscle. Cell. Mol. Life Sci. 2019, 76, 2559-2570. [CrossRef]

10. Chang, N.C.; Rudnicki, M.A. Satellite Cells. In Current Topics in Developmental Biology; Elsevier: Amsterdam, The Netherlands, 2014; Volume 107, pp. 161-181. ISBN 978-0-12-416022-4.

11. Kang, X.; Yang, M.; Shi, Y.; Xie, M.; Zhu, M.; Zheng, X.; Zhang, C.; Ge, Z.; Bian, X.; Lv, J.; et al. Interleukin-15 Facilitates Muscle Regeneration through Modulation of Fibro/Adipogenic Progenitors. Cell Commun. Signal. 2018, 16, 42. [CrossRef]

12. Joe, A.W.B.; Yi, L.; Natarajan, A.; Le Grand, F.; So, L.; Wang, J.; Rudnicki, M.A.; Rossi, F.M.V. Muscle Injury Activates Resident Fibro/Adipogenic Progenitors That Facilitate Myogenesis. Nat. Cell Biol. 2010, 12, 153-163. [CrossRef] [PubMed] 
13. Moratal, C.; Raffort, J.; Arrighi, N.; Rekima, S.; Schaub, S.; Dechesne, C.A.; Chinetti, G.; Dani, C. IL-1 $\beta$ - and IL-4-Polarized Macrophages Have Opposite Effects on Adipogenesis of Intramuscular Fibro-Adipogenic Progenitors in Humans. Sci. Rep. 2018, 8, 17005. [CrossRef] [PubMed]

14. Heredia, J.E.; Mukundan, L.; Chen, F.M.; Mueller, A.A.; Deo, R.C.; Locksley, R.M.; Rando, T.A.; Chawla, A. Type 2 Innate Signals Stimulate Fibro/Adipogenic Progenitors to Facilitate Muscle Regeneration. Cell 2013, 153, 376-388. [CrossRef]

15. Santini, M.P.; Malide, D.; Hoffman, G.; Pandey, G.; D’Escamard, V.; Nomura-Kitabayashi, A.; Rovira, I.; Kataoka, H.; Ochando, J.; Harvey, R.P.; et al. Tissue-Resident PDGFR $\alpha+$ Progenitor Cells Contribute to Fibrosis versus Healing in a Context- and Spatiotemporally Dependent Manner. Cell Rep. 2020, 30, 555-570.e7. [CrossRef]

16. Uezumi, A.; Fukada, S.; Yamamoto, N.; Takeda, S.; Tsuchida, K. Mesenchymal Progenitors Distinct from Satellite Cells Contribute to Ectopic Fat Cell Formation in Skeletal Muscle. Nat. Cell Biol. 2010, 12, 143-152. [CrossRef]

17. Shefer, G.; Wleklinski-Lee, M.; Yablonka-Reuveni, Z. Skeletal Muscle Satellite Cells Can Spontaneously Enter an Alternative Mesenchymal Pathway. J. Cell Sci. 2004, 117, 5393-5404. [CrossRef]

18. Li, Y.; Huard, J. Differentiation of Muscle-Derived Cells into Myofibroblasts in Injured Skeletal Muscle. Am. J. Pathol. 2002, 161, 895-907. [CrossRef]

19. Järvinen, T.A.H.; Järvinen, T.L.N.; Kääriäinen, M.; Kalimo, H.; Järvinen, M. Muscle Injuries: Biology and Treatment. Am. J. Sports Med. 2005, 33, 745-764. [CrossRef] [PubMed]

20. Brancaccio, P.; Lippi, G.; Maffulli, N. Biochemical Markers of Muscular Damage. Clin. Chem. Lab. Med. 2010, 48, 757-767. [CrossRef]

21. Gaudenzio, N.; Sibilano, R.; Marichal, T.; Starkl, P.; Reber, L.L.; Cenac, N.; McNeil, B.D.; Dong, X.; Hernandez, J.D.; SagiEisenberg, R.; et al. Different Activation Signals Induce Distinct Mast Cell Degranulation Strategies. J. Clin. Investig. 2016, 126, 3981-3998. [CrossRef]

22. Zhang, C.; Wang, C.; Li, Y.; Miwa, T.; Liu, C.; Cui, W.; Song, W.-C.; Du, J. Complement C3a Signaling Facilitates Skeletal Muscle Regeneration by Regulating Monocyte Function and Trafficking. Nat. Commun. 2017, 8, 2078. [CrossRef]

23. Scaffidi, P.; Misteli, T.; Bianchi, M.E. Release of Chromatin Protein HMGB1 by Necrotic Cells Triggers Inflammation. Nature 2002, 418, 191-195. [CrossRef]

24. Frenette, J.; Cai, B.; Tidball, J.G. Complement Activation Promotes Muscle Inflammation during Modified Muscle Use. Am. J. Pathol. 2000, 156, 2103-2110. [CrossRef]

25. Duchesne, E.; Bouchard, P.; Roussel, M.-P.; Côté, C.H. Mast Cells Can Regulate Skeletal Muscle Cell Proliferation by Multiple Mechanisms: Mast Cells and Muscle Healing. Muscle Nerve 2013, 48, 403-414. [CrossRef]

26. Yang, W.; Hu, P. Skeletal Muscle Regeneration Is Modulated by Inflammation. J. Orthop. Transl. 2018, 13, 25-32. [CrossRef]

27. Duchesne, E.; Dufresne, S.S.; Dumont, N.A. Impact of Inflammation and Anti-Inflammatory Modalities on Skeletal Muscle Healing: From Fundamental Research to the Clinic. Phys. Ther. 2017, 97, 807-817. [CrossRef] [PubMed]

28. Dumont, N.; Bouchard, P.; Frenette, J. Neutrophil-Induced Skeletal Muscle Damage: A Calculated and Controlled Response Following Hindlimb Unloading and Reloading. Am. J. Physiol.-Regul. Integr. Comp. Physiol. 2008, 295, R1831-R1838. [CrossRef]

29. Qazi, T.H.; Duda, G.N.; Ort, M.J.; Perka, C.; Geissler, S.; Winkler, T. Cell Therapy to Improve Regeneration of Skeletal Muscle Injuries. J. Cachexia Sarcopenia Muscle 2019, 10, 501-516. [CrossRef] [PubMed]

30. Montarras, D. Direct Isolation of Satellite Cells for Skeletal Muscle Regeneration. Science 2005, 309, 2064-2067. [CrossRef]

31. Collins, C.A.; Olsen, I.; Zammit, P.S.; Heslop, L.; Petrie, A.; Partridge, T.A.; Morgan, J.E. Stem Cell Function, Self-Renewal, and Behavioral Heterogeneity of Cells from the Adult Muscle Satellite Cell Niche. Cell 2005, 122, 289-301. [CrossRef]

32. Sacco, A.; Doyonnas, R.; Kraft, P.; Vitorovic, S.; Blau, H.M. Self-Renewal and Expansion of Single Transplanted Muscle Stem Cells. Nature 2008, 456, 502-506. [CrossRef] [PubMed]

33. Webster, M.T.; Manor, U.; Lippincott-Schwartz, J.; Fan, C.-M. Intravital Imaging Reveals Ghost Fibers as Architectural Units Guiding Myogenic Progenitors during Regeneration. Cell Stem Cell 2016, 18, 243-252. [CrossRef]

34. Cerletti, M.; Jurga, S.; Witczak, C.A.; Hirshman, M.F.; Shadrach, J.L.; Goodyear, L.J.; Wagers, A.J. Highly Efficient, Functional Engraftment of Skeletal Muscle Stem Cells in Dystrophic Muscles. Cell 2008, 134, 37-47. [CrossRef] [PubMed]

35. Usas, A.; Huard, J. Muscle-Derived Stem Cells for Tissue Engineering and Regenerative Therapy. Biomaterials 2007, 28, 5401-5406. [CrossRef]

36. Lorant, J.; Saury, C.; Schleder, C.; Robriquet, F.; Lieubeau, B.; Négroni, E.; Leroux, I.; Chabrand, L.; Viau, S.; Babarit, C.; et al. Skeletal Muscle Regenerative Potential of Human MuStem Cells Following Transplantation into Injured Mice Muscle. Mol. Ther. 2018, 26, 618-633. [CrossRef]

37. Trucillo, E.; Bisceglia, B.; Valdrè, G.; Giordano, E.; Reverchon, E.; Maffulli, N.; Della Porta, G. Growth Factor Sustained Delivery from Poly-lactic-co-glycolic Acid Microcarriers and Its Mass Transfer Modeling by Finite Element in a Dynamic and Static Three-dimensional Environment Bioengineered with Stem Cells. Biotechnol. Bioeng. 2019, 116, 1777-1794. [CrossRef]

38. Lamparelli, E.P.; Lovecchio, J.; Ciardulli, M.C.; Giudice, V.; Dale, T.P.; Selleri, C.; Forsyth, N.; Giordano, E.; Maffulli, N.; Della Porta, G. Chondrogenic Commitment of Human Bone Marrow Mesenchymal Stem Cells in a Perfused Collagen Hydrogel Functionalized with HTGF-B1-Releasing PLGA Microcarrier. Pharmaceutics 2021, 13, 399. [CrossRef] [PubMed]

39. Ciardulli, M.C.; Marino, L.; Lovecchio, J.; Giordano, E.; Forsyth, N.R.; Selleri, C.; Maffulli, N.; Della Porta, G. Tendon and Cytokine Marker Expression by Human Bone Marrow Mesenchymal Stem Cells in a Hyaluronate/Poly-Lactic-Co-Glycolic Acid (PLGA)/Fibrin Three-Dimensional (3D) Scaffold. Cells 2020, 9, 1268. [CrossRef] 
40. Ciardulli, M.C.; Marino, L.; Lamparelli, E.P.; Guida, M.; Forsyth, N.R.; Selleri, C.; Della Porta, G.; Maffulli, N. Dose-Response Tendon-Specific Markers Induction by Growth Differentiation Factor-5 in Human Bone Marrow and Umbilical Cord Mesenchymal Stem Cells. Int. J. Mol. Sci. 2020, 21, 5905. [CrossRef]

41. Ciardulli, M.C.; Lovecchio, J.; Scala, P.; Lamparelli, E.P.; Dale, T.P.; Giudice, V.; Giordano, E.; Selleri, C.; Forsyth, N.R.; Maffulli, N.; et al. 3D Biomimetic Scaffold for Growth Factor Controlled Delivery: An In-Vitro Study of Tenogenic Events on Wharton's Jelly Mesenchymal Stem Cells. Pharmaceutics 2021, 13, 1448. [CrossRef]

42. Scala, P.; Lovecchio, J.; Lamparelli, E.P.; Vitolo, R.; Giudice, V.; Giordano, E.; Selleri, C.; Rehak, L.; Maffulli, N.; Della Porta, G. Myogenic Commitment of Human Stem Cells by Myoblasts Co-Culture: A Static Vs. Dynamic Approach. Artif. Cells Nanomed. Biotechnol. 2021. In press.

43. Elahi, K.C.; Klein, G.; Avci-Adali, M.; Sievert, K.D.; MacNeil, S.; Aicher, W.K. Human Mesenchymal Stromal Cells from Different Sources Diverge in Their Expression of Cell Surface Proteins and Display Distinct Differentiation Patterns. Stem Cells Int. 2016, 2016, 5646384. [CrossRef] [PubMed]

44. Winkler, T.; von Roth, P.; Matziolis, G.; Mehta, M.; Perka, C.; Duda, G.N. Dose-Response Relationship of Mesenchymal Stem Cell Transplantation and Functional Regeneration after Severe Skeletal Muscle Injury in Rats. Tissue Eng. Part A 2009, 15, 487-492. [CrossRef]

45. Matziolis, G.; Winkler, T.; Schaser, K.; Wiemann, M.; Krocker, D.; Tuischer, J.; Perka, C.; Duda, G.N. Autologous Bone MarrowDerived Cells Enhance Muscle Strength Following Skeletal Muscle Crush Injury in Rats. Tissue Eng. 2006, 12, 361-367. [CrossRef] [PubMed]

46. Von Roth, P.; Duda, G.N.; Radojewski, P.; Preininger, B.; Strohschein, K.; Röhner, E.; Perka, C.; Winkler, T. Intra-Arterial MSC Transplantation Restores Functional Capacity After Skeletal Muscle Trauma. Open Orthop. J. 2012, 6, 352-356. [CrossRef]

47. Peçanha, R.; de Bagno, L.L.E.S.; Ribeiro, M.B.; Robottom Ferreira, A.B.; Moraes, M.O.; Zapata-Sudo, G.; Kasai-Brunswick, T.H.; Campos-de-Carvalho, A.C.; dos Goldenberg, R.C.S.; Saar Werneck-de-Castro, J.P. Adipose-Derived Stem-Cell Treatment of Skeletal Muscle Injury. J. Bone Jt. Surg. 2012, 94, 609-617. [CrossRef]

48. Helal, M.A.M.; Shaheen, N.E.M.; Abu Zahra, F.A. Immunomodulatory Capacity of the Local Mesenchymal Stem Cells Transplantation after Severe Skeletal Muscle Injury in Female Rats. Immunopharmacol. Immunotoxicol. 2016, 38, 414-422. [CrossRef]

49. Liu, X.; Zheng, L.; Zhou, Y.; Chen, Y.; Chen, P.; Xiao, W. BMSC Transplantation Aggravates Inflammation, Oxidative Stress, and Fibrosis and Impairs Skeletal Muscle Regeneration. Front. Physiol. 2019, 10, 87. [CrossRef] [PubMed]

50. Shapouri-Moghaddam, A.; Mohammadian, S.; Vazini, H.; Taghadosi, M.; Esmaeili, S.; Mardani, F.; Seifi, B.; Mohammadi, A.; Afshari, J.T.; Sahebkar, A. Macrophage Plasticity, Polarization, and Function in Health and Disease. J. Cell. Physiol. 2018, 233, 6425-6440. [CrossRef]

51. Tidball, J.G.; Villalta, S.A. Regulatory Interactions between Muscle and the Immune System during Muscle Regeneration. Am. J. Physiol.-Regul. Integr. Comp. Physiol. 2010, 298, R1173-R1187. [CrossRef] [PubMed]

52. Gordon, S.; Taylor, P.R. Monocyte and Macrophage Heterogeneity. Nat. Rev. Immunol. 2005, 5, 953-964. [CrossRef]

53. Stout, R.D.; Jiang, C.; Matta, B.; Tietzel, I.; Watkins, S.K.; Suttles, J. Macrophages Sequentially Change Their Functional Phenotype in Response to Changes in Microenvironmental Influences. J. Immunol. 2005, 175, 342-349. [CrossRef]

54. Deng, B.; Wehling-Henricks, M.; Villalta, S.A.; Wang, Y.; Tidball, J.G. IL-10 Triggers Changes in Macrophage Phenotype That Promote Muscle Growth and Regeneration. J. Immunol. 2012, 189, 3669-3680. [CrossRef]

55. Brigitte, M.; Schilte, C.; Plonquet, A.; Baba-Amer, Y.; Henri, A.; Charlier, C.; Tajbakhsh, S.; Albert, M.; Gherardi, R.K.; Chrétien, F. Muscle Resident Macrophages Control the Immune Cell Reaction in a Mouse Model of Notexin-Induced Myoinjury. Arthritis Rheum. 2010, 62, 268-279. [CrossRef]

56. Chazaud, B.; Sonnet, C.; Lafuste, P.; Bassez, G.; Rimaniol, A.-C.; Poron, F.; Authier, F.-J.; Dreyfus, P.A.; Gherardi, R.K. Satellite Cells Attract Monocytes and Use Macrophages as a Support to Escape Apoptosis and Enhance Muscle Growth. J. Cell Biol. 2003, 163, 1133-1143. [CrossRef]

57. Zouaoui Boudjeltia, K.; Moguilevsky, N.; Legssyer, I.; Babar, S.; Guillaume, M.; Delree, P.; Vanhaeverbeek, M.; Brohee, D.; Ducobu, J.; Remacle, C. Oxidation of Low Density Lipoproteins by Myeloperoxidase at the Surface of Endothelial Cells: An Additional Mechanism to Subendothelium Oxidation. Biochem. Biophys. Res. Commun. 2004, 325, 434-438. [CrossRef]

58. Arnold, L.; Henry, A.; Poron, F.; Baba-Amer, Y.; van Rooijen, N.; Plonquet, A.; Gherardi, R.K.; Chazaud, B. Inflammatory Monocytes Recruited after Skeletal Muscle Injury Switch into Antiinflammatory Macrophages to Support Myogenesis. J. Exp. Med. 2007, 204, 1057-1069. [CrossRef] [PubMed]

59. Suelves, M.; López-Alemany, R.; Lluís, F.; Aniorte, G.; Serrano, E.; Parra, M.; Carmeliet, P.; Muñoz-Cánoves, P. Plasmin Activity Is Required for Myogenesis in Vitro and Skeletal Muscle Regeneration in Vivo. Blood 2002, 99, 2835-2844. [CrossRef] [PubMed]

60. Novak, M.L.; Bryer, S.C.; Cheng, M.; Nguyen, M.-H.; Conley, K.L.; Cunningham, A.K.; Xue, B.; Sisson, T.H.; You, J.-S.; Hornberger, T.A.; et al. Macrophage-Specific Expression of Urokinase-Type Plasminogen Activator Promotes Skeletal Muscle Regeneration. J. Immunol. 2011, 187, 1448-1457. [CrossRef] [PubMed]

61. Koh, T.J.; Bryer, S.C.; Pucci, A.M.; Sisson, T.H. Mice Deficient in Plasminogen Activator Inhibitor-1 Have Improved Skeletal Muscle Regeneration. Am. J. Physiol.-Cell Physiol. 2005, 289, C217-C223. [CrossRef] [PubMed]

62. Varga, T.; Mounier, R.; Horvath, A.; Cuvellier, S.; Dumont, F.; Poliska, S.; Ardjoune, H.; Juban, G.; Nagy, L.; Chazaud, B. Highly Dynamic Transcriptional Signature of Distinct Macrophage Subsets during Sterile Inflammation, Resolution, and Tissue Repair. J. Immunol. 2016, 196, 4771-4782. [CrossRef] 
63. Novak, M.L.; Weinheimer-Haus, E.M.; Koh, T.J. Macrophage Activation and Skeletal Muscle Healing Following Traumatic Injury: Macrophage Activation in Muscle Trauma. J. Pathol. 2014, 232, 344-355. [CrossRef] [PubMed]

64. Perdiguero, E.; Sousa-Victor, P.; Ruiz-Bonilla, V.; Jardí, M.; Caelles, C.; Serrano, A.L.; Muñoz-Cánoves, P. P38/MKP-1-Regulated AKT Coordinates Macrophage Transitions and Resolution of Inflammation during Tissue Repair. J. Cell Biol. 2011, 195, 307-322. [CrossRef] [PubMed]

65. Mounier, R.; Théret, M.; Arnold, L.; Cuvellier, S.; Bultot, L.; Göransson, O.; Sanz, N.; Ferry, A.; Sakamoto, K.; Foretz, M.; et al. AMPK $\alpha 1$ Regulates Macrophage Skewing at the Time of Resolution of Inflammation during Skeletal Muscle Regeneration. Cell Metab. 2013, 18, 251-264. [CrossRef] [PubMed]

66. Wang, H.; Melton, D.W.; Porter, L.; Sarwar, Z.U.; McManus, L.M.; Shireman, P.K. Altered Macrophage Phenotype Transition Impairs Skeletal Muscle Regeneration. Am. J. Pathol. 2014, 184, 1167-1184. [CrossRef]

67. Côté, C.H.; Bouchard, P.; van Rooijen, N.; Marsolais, D.; Duchesne, E. Monocyte Depletion Increases Local Proliferation of Macrophage Subsets after Skeletal Muscle Injury. BMC Musculoskelet. Disord. 2013, 14, 359. [CrossRef]

68. Summan, M.; Warren, G.L.; Mercer, R.R.; Chapman, R.; Hulderman, T.; Van Rooijen, N.; Simeonova, P.P. Macrophages and Skeletal Muscle Regeneration: A Clodronate-Containing Liposome Depletion Study. Am. J. Physiol.-Regul. Integr. Comp. Physiol. 2006, 290, R1488-R1495. [CrossRef]

69. Warren, G.L.; Hulderman, T.; Mishra, D.; Gao, X.; Millecchia, L.; O’Farrell, L.; Kuziel, W.A.; Simeonova, P.P. Chemokine Receptor CCR2 Involvement in Skeletal Muscle Regeneration. FASEB J. 2005, 19, 1-23. [CrossRef]

70. Contreras-Shannon, V.; Ochoa, O.; Reyes-Reyna, S.M.; Sun, D.; Michalek, J.E.; Kuziel, W.A.; McManus, L.M.; Shireman, P.K. Fat Accumulation with Altered Inflammation and Regeneration in Skeletal Muscle of CCR2 ${ }^{-/-}$Mice Following Ischemic Injury. Am. J. Physiol.-Cell Physiol. 2007, 292, C953-C967. [CrossRef]

71. Lu, H.; Huang, D.; Saederup, N.; Charo, I.F.; Ransohoff, R.M.; Zhou, L. Macrophages Recruited via CCR2 Produce Insulin-like Growth Factor-1 to Repair Acute Skeletal Muscle Injury. FASEB J. 2011, 25, 358-369. [CrossRef]

72. Lu, H.; Huang, D.; Ransohoff, R.M.; Zhou, L. Acute Skeletal Muscle Injury: CCL2 Expression by Both Monocytes and Injured Muscle Is Required for Repair. FASEB J. 2011, 25, 3344-3355. [CrossRef] [PubMed]

73. Shireman, P.K.; Contreras-Shannon, V.; Ochoa, O.; Karia, B.P.; Michalek, J.E.; McManus, L.M. MCP-1 Deficiency Causes Altered Inflammation with Impaired Skeletal Muscle Regeneration. J. Leukoc. Biol. 2007, 81, 775-785. [CrossRef]

74. Rybalko, V.; Hsieh, P.-L.; Merscham-Banda, M.; Suggs, L.J.; Farrar, R.P. The Development of Macrophage-Mediated Cell Therapy to Improve Skeletal Muscle Function after Injury. PLoS ONE 2015, 10, e0145550. [CrossRef] [PubMed]

75. Ratnayake, D.; Nguyen, P.D.; Rossello, F.J.; Wimmer, V.C.; Tan, J.L.; Galvis, L.A.; Julier, Z.; Wood, A.J.; Boudier, T.; Isiaku, A.I.; et al Macrophages Provide a Transient Muscle Stem Cell Niche via NAMPT Secretion. Nature 2021, 591, 281-287. [CrossRef]

76. Sonnet, C. Human Macrophages Rescue Myoblasts and Myotubes from Apoptosis through a Set of Adhesion Molecular Systems. J. Cell Sci. 2006, 119, 2497-2507. [CrossRef]

77. Choo, H.-J.; Canner, J.P.; Vest, K.E.; Thompson, Z.; Pavlath, G.K. A Tale of Two Niches: Differential Functions for VCAM-1 in Satellite Cells under Basal and Injured Conditions. Am. J. Physiol.-Cell Physiol. 2017, 313, C392-C404. [CrossRef] [PubMed]

78. Saclier, M.; Yacoub-Youssef, H.; Mackey, A.L.; Arnold, L.; Ardjoune, H.; Magnan, M.; Sailhan, F.; Chelly, J.; Pavlath, G.K.; Mounier, R.; et al. Differentially Activated Macrophages Orchestrate Myogenic Precursor Cell Fate During Human Skeletal Muscle Regeneration. Stem Cells 2013, 31, 384-396. [CrossRef]

79. Cantini, M.; Giurisato, E.; Radu, C.; Tiozzo, S.; Pampinella, F.; Senigaglia, D.; Zaniolo, G.; Mazzoleni, F.; Vitiello, L. MacrophageSecreted Myogenic Factors: A Promising Tool for Greatly Enhancing the Proliferative Capacity of Myoblasts in Vitro and in Vivo. Neurol. Sci. 2002, 23, 189-194. [CrossRef]

80. Chen, S.-E.; Jin, B.; Li, Y.-P. TNF- $\alpha$ Regulates Myogenesis and Muscle Regeneration by Activating P38 MAPK. Am. J. Physiol.-Cell Physiol. 2007, 292, C1660-C1671. [CrossRef]

81. Zhao, Q.; Yang, S.T.; Wang, J.J.; Zhou, J.; Xing, S.S.; Shen, C.C.; Wang, X.X.; Yue, Y.X.; Song, J.; Chen, M.; et al. TNF Alpha Inhibits Myogenic Differentiation of C2C12 Cells through NF-KB Activation and Impairment of IGF-1 Signaling Pathway. Biochem. Biophys. Res. Commun. 2015, 458, 790-795. [CrossRef]

82. Li, Y.-P. TNF- $\alpha$ Is a Mitogen in Skeletal Muscle. Am. J. Physiol.-Cell Physiol. 2003, 285, C370-C376. [CrossRef] [PubMed]

83. Torrente, Y.; Fahime, E.E.; Caron, N.J.; Del Bo, R.; Belicchi, M.; Pisati, F.; Tremblay, J.P.; Bresolin, N. Tumor Necrosis Factor- $\alpha$ (TNF- $\alpha$ ) Stimulates Chemotactic Response in Mouse Myogenic Cells. Cell Transplant. 2003, 12, 91-100. [CrossRef] [PubMed]

84. Warren, G.L.; Hulderman, T.; Jensen, N.; McKinstry, M.; Mishra, M.; Luster, M.I.; Simeonova, P.P. Physiological Role of Tumor Necrosis Factor $\alpha$ in Traumatic Muscle Injury. FASEB J. 2002, 16, 1630-1632. [CrossRef]

85. Langen, R.C.J.; Velden, J.L.J.; Schols, A.M.W.J.; Kelders, M.C.J.M.; Wouters, E.F.M.; Janssen-Heininger, Y.M.W. Tumor Necrosis Factor- $\alpha$ Inhibits Myogenic Differentiation through MyoD Protein Destabilization. FASEB J. 2004, 18, 227-237. [CrossRef] [PubMed]

86. Londhe, P.; Davie, J.K. Gamma Interferon Modulates Myogenesis through the Major Histocompatibility Complex Class II Transactivator, CIITA. Mol. Cell. Biol. 2011, 31, 2854-2866. [CrossRef]

87. Cheng, M.; Nguyen, M.-H.; Fantuzzi, G.; Koh, T.J. Endogenous Interferon- $\gamma$ Is Required for Efficient Skeletal Muscle Regeneration. Am. J. Physiol.-Cell Physiol. 2008, 294, C1183-C1191. [CrossRef]

88. Foster, W.; Li, Y.; Usas, A.; Somogyi, G.; Huard, J. Gamma Interferon as an Antifibrosis Agent in Skeletal Muscle. J. Orthop. Res. 2003, 21, 798-804. [CrossRef] 
89. Serrano, A.L.; Baeza-Raja, B.; Perdiguero, E.; Jardí, M.; Muñoz-Cánoves, P. Interleukin-6 Is an Essential Regulator of Satellite Cell-Mediated Skeletal Muscle Hypertrophy. Cell Metab. 2008, 7, 33-44. [CrossRef]

90. Zhang, C.; Li, Y.; Wu, Y.; Wang, L.; Wang, X.; Du, J. Interleukin-6/Signal Transducer and Activator of Transcription 3 (STAT3) Pathway Is Essential for Macrophage Infiltration and Myoblast Proliferation during Muscle Regeneration. J. Biol. Chem. 2013, 288, 1489-1499. [CrossRef]

91. Steyn, P.J.; Dzobo, K.; Smith, R.I.; Myburgh, K.H. Interleukin-6 Induces Myogenic Differentiation via JAK2-STAT3 Signaling in Mouse C2C12 Myoblast Cell Line and Primary Human Myoblasts. Int. J. Mol. Sci. 2019, 20, 5273. [CrossRef]

92. Grabiec, K.; Tokarska, J.; Milewska, M.; Błaszczyk, M.; Gajewska, M.; Grzelkowska-Kowalczyk, K. Interleukin-1ß Stimulates Early Myogenesis of Mouse C2C12 Myoblasts: The Impact on Myogenic Regulatory Factors, Extracellular Matrix Components, IGF Binding Proteins and Protein Kinases. Pol. J. Vet. Sci. 2013, 16, 255-264. [CrossRef]

93. Li, W.; Moylan, J.S.; Chambers, M.A.; Smith, J.; Reid, M.B. Interleukin-1 Stimulates Catabolism in C2C12 Myotubes. Am. J. Physiol.-Cell Physiol. 2009, 297, C706-C714. [CrossRef] [PubMed]

94. Chaweewannakorn, C.; Tsuchiya, M.; Koide, M.; Hatakeyama, H.; Tanaka, Y.; Yoshida, S.; Sugawara, S.; Hagiwara, Y.; Sasaki, K.; Kanzaki, M. Roles of IL- $1 \alpha / \beta$ in Regeneration of Cardiotoxin-Injured Muscle and Satellite Cell Function. Am. J. Physiol.-Regul. Integr. Comp. Physiol. 2018, 315, R90-R103. [CrossRef] [PubMed]

95. Otis, J.S.; Niccoli, S.; Hawdon, N.; Sarvas, J.L.; Frye, M.A.; Chicco, A.J.; Lees, S.J. Pro-Inflammatory Mediation of Myoblast Proliferation. PLOS ONE 2014, 9, e92363. [CrossRef]

96. Liu, X.; Zeng, Z.; Zhao, L.; Xiao, W.; Chen, P. Changes in Inflammatory and Oxidative Stress Factors and the Protein Synthesis Pathway in Injured Skeletal Muscle after Contusion. Exp. Ther. Med. 2017, 15, 2196-2202. [CrossRef]

97. Jung, H.-G.; Ahn, E.-K.; Lee, J.-H.; Kim, Y.-H.; Leem, S.-H.; Heo, J.; Kim, H. Effects of Harvesting Sites and Ages on Adipose Tissue-Derived Stem Cells in Rat. Tissue Eng. Regen. Med. 2014, 11, 137-142. [CrossRef]

98. Cianfarani, F.; Toietta, G.; Di Rocco, G.; Cesareo, E.; Zambruno, G.; Odorisio, T. Diabetes Impairs Adipose Tissue-Derived Stem Cell Function and Efficiency in Promoting Wound Healing: Impaired Prohealing Function of Diabetic ASCs. Wound Repair Regen. 2013, 21, 545-553. [CrossRef]

99. Mueller, S.M.; Glowacki, J. Age-Related Decline in the Osteogenic Potential of Human Bone Marrow Cells Cultured in ThreeDimensional Collagen Sponges. J. Cell. Biochem. 2001, 82, 583-590. [CrossRef]

100. Zhang, M.; Huang, B. The Multi-Differentiation Potential of Peripheral Blood Mononuclear Cells. Stem Cell Res. Ther. $2012,3,48$. [CrossRef] [PubMed]

101. Spaltro, G.; Straino, S.; Gambini, E.; Bassetti, B.; Persico, L.; Zoli, S.; Zanobini, M.; Capogrossi, M.C.; Spirito, R.; Quarti, C.; et al. Characterization of the Pall Celeris System as a Point-of-Care Device for Therapeutic Angiogenesis. Cytotherapy 2015, 17, 1302-1313. [CrossRef]

102. Rigato, M.; Monami, M.; Fadini, G.P. Autologous Cell Therapy for Peripheral Arterial Disease: Systematic Review and MetaAnalysis of Randomized, Nonrandomized, and Noncontrolled Studies. Circ. Res. 2017, 120, 1326-1340. [CrossRef] [PubMed] 